\title{
Integrasi Prinsip Syariah dalam Fungsi Intermediasi Lembaga Keuangan Syariah
}

\author{
Dewi Sukma Kristianti \\ Fakultas Hukum Universitas Katolik Parahyangan \\ dewi.sukma@unpar.ac.id
}

\begin{abstract}
As a financial intermediary institution, Sharia Financial Institutions (LKS) have the responsibility to carry out their business activities by complying with sharia principles, which in the Indonesian context are stated in a number of Fatwas from the National Sharia Council-Indonesian Ulema Council (DSN-MUI). This article discusses why compliance with sharia principles has so far been a problem in LKS business activities, even though the presence of LKS in Indonesia has been nearly a quarter of a century. In this article it is shown that the legal substance of the principles of sharia, as stated in a number of DSN-MUI Fatwas, is still general in nature, so it is not operational and leads to inappropriate interpretations. As a result, the intermediation function of LKS is equated with the intermediation function of conventional financial institutions, and Islamic financing is also equated with credit or receivables. Apart from the fact that the provisions in the DSN-MUI Fatwa are still abstract, another factor that causes the practice not to comply with sharia principles is the weakness of the supervisory element in the LKS, namely the sharia supervisory board (DPS), which is placed parallel to the board of directors, making supervision difficult to be effective. Moreover, DPS membership turned out to be possible to be concurrently in several LKS, so that the supervisory function was not focused and was potentially biased. In the future, it is hoped that the fatwa will contain more operational content and institutional supervision must be made effective and focused.
\end{abstract}

Keywords: sharia principles; intermediation function; DSN-MUI fatwa; integration. 


\section{Abstrak}

Sebagai lembaga intermediasi keuangan, Lembaga Keuangan Syariah (LKS) memiliki tanggung jawab untuk melaksanakan kegiatan usahanya dengan memenuhi prinsip syariah, yang dalam konteks Indonesia sebagaimana tercantum dalam sejumlah Fatwa Dewan Syariah NasionalMajelis Ulama Indonesia (DSN-MUI). Artikel ini membahas mengapa kepatuhan prinsip-prinsip syariah sejauh ini masih menjadi persoalan dalam kegiatan usaha LKS, padahal kehadiran LKS di Indonesia sudah hampir seperempat abad lebih. Dalam artikel ini ditunjukkan, substansi hukum tentang prinsip-pinsip syariah, sebagaimana yang tercantum dalam sejumlah Fatwa DSN-MUI, masih bersifat umum, sehingga tidak operasional dan menimbulkan interpretasi yang tidak tepat. Akibatnya, fungsi intermediasi LKS disamakan dengan fungsi intermediasi Iembaga keuangan konvensional, dan pembiayaan syariah disamakan pula dengan kredit atau utang piutang. Selain ketentuan dalam Fatwa DSNMUI yang masih abstrak, faktor lain yang menyebabkan ketidakpatuhan pada prinsip syariah adalah lemahnya unsur pengawas dalam LKS, yaitu dewan pengawas syariah (DPS), yang ditempatkan sejajar dengan direksi, sehingga pengawasan menjadi sulit efektif. Terlebih lagi keanggotaan DPS ternyata dimungkinkan untuk dirangkap dalam beberapa LKS, sehingga fungsi pengawasan tidak terfokus dan potensial bias. Ke depan diharapkan fatwa berisi materi muatan yang lebih operasional, dan kelembagaan pengawasan juga mesti dibuat efektif dan terfokus.

Kata Kunci: prinsip syariah; fungsi intermediasi; fatwa DSN-MUI; integrasi.

\section{A. Pendahuluan}

Artikel ini membahas integrasi prinsip-prinsip syariah oleh Lembaga Keuangan Syariah (LKS) dalam menjalankan fungsi intermediasi, yaitu suatu fungsi yang mempertemukan antar masyarakat melalui kegiatan penghimpunan dan penyaluran dana. Permasalahan yang didiskusikan adalah, mengapa prinsip-prinsip syariah dalam kegiatan intermediasi LKS sejauh ini belum terintegrasi dengan baik dan bagaimana upaya ke depannya agar integrasi menjadi lebih baik. Dalam artikel ini, pembahasan integrasi prinsip-prinsip syariah 
dalam kegiatan LKS dilakukan melalui penelaahan pada norma yang mengatur prinsip-prinsip syariah dan kelembagaan pengawasan LKS.

Pembahasan persoalan integrasi prinsip syariah dalam fungsi intermediasi oleh LKS ini dilatarbelakangi oleh tiga alasan. Pertama, integrasi prinsip syariah dalam kegiatan intermediasi LKS merupakan suatu keharusan. Keharusan ini disebabkan karena LKS merupakan suatu lembaga keuangan yang menggunakan nilai dan prinsip syariah dalam setiap transaksi keuangan yang dilakukan, sehingga bagaimana mungkin suatu lembaga keuangan yang telah menetapkan penggunaan kata "syariah" tidak patuh pada ketentuan yang telah ditetapkan dalam prinsip syariah. Setiap kegiatan transaksi yang dilakukan sudah barang tentu merupakan perwujudan dari prinsip-prinsip syariah. Di samping itu latar belakang hadirnya LKS sendiri merupakan suatu lembaga keuangan yang ingin memberikan jaminan kehalalan produk keuangannya yang sesuai dengan prinsip syariah. ${ }^{1}$

Kedua, keberadaan LKS di Indonesia saat ini telah mencapai usia lebih 25 tahun. Dalam dua dasawarsa lebih perjalanannya itu, tentu menjadi penting untuk direfleksikan bagaimana kepatuhannya pada prinsip-prinsip syariah. Usia ini tentu tidaklah muda, namun juga masih cukup jauh bila dibanding dengan kehadiran lembaga keuangan konvensional. Kehadiran LKS sebenarnya sudah ada sejak tahun 1991, namun memang semakin semarak dengan ditandai banyaknya LKS-LKS yang hadir di Indonesia setelah ditetapkannya dual banking system di Indonesia melalui Undang-Undang Nomor 10 Tahun 1998 tentang Perubahan atas Undang-Undang Nomor 7 Tahun 1992 tentang Perbankan. Selama kurun waktu tersebut, persoalan yang masih kerap terjadi adalah praktik-praktik akad yang dilakukan oleh LKS masih banyak yang menimbulkan pertanyaan masyarakat, misalnya apakah akad yang digunakan untuk suatu produk syariah telah sesuai atau tidak, serta apakah produk LKS yang dikeluarkan

1 Arief Budiono, "Penerapan Prinsip Syariah pada Lembaga Keuangan Syariah", Law and Justice, 2, 1 (2017), hlm. 55-56. 
telah dijamin kehalalannya. ${ }^{2} \mathrm{Hal}$ ini menunjukkan bahwa persoalan kepatuhan syariah masih selalu menjadi persoalan karena belum terintegrasi secara penuh dalam kegiatan LKS.

Ketiga, dalam berbagai penelitian terungkap bahwa ada indikasi prinsip-prinsip syariah tidak dipatuhi oleh LKS. Hal ini terlihat dari kajian yang dilakukan oleh para akademisi maupun praktisi LKS. Lina Maulidiana misalnya, mengkritisi mengenai lembaga keuangan yang berkomitmen memenuhi tujuan dalam prinsip syariah untuk senantiasa menjalankan berkegiatan yang sesuai dengan prinsip syariah. ${ }^{3}$ Kajian Arief Budiono juga menyimpulkan, baik dalam Undang-Undang maupun peraturan lainnya di bidang LKS, masih belum sepenuhnya mendukung tujuan dari prinsip-prinsip syariah, sehingga terjadi ketidaksesuaian antara praktik LKS dan fatwa yang dikeluarkan oleh Dewan Syariah Nasional yang menetapkan prinsip syariah yang harus dipatuhi $\mathrm{LKS}^{4}{ }^{4}$ Sedangkan kajian dari Sepky Mardian menyimpulkan, banyaknya LKS di Indonesia yang bermasalah pada kepatuhan prinsip syariah dikarenakan tata kelola yang buruk, serta peran Dewan Pengawas Syariah yang belum maksimal dalam mengawasi kepatuhan syariah yang dilakukan LKS. ${ }^{5}$ Hasil kajian Sugeng Widodo dan Nuhbatul Basyariah juga menyimpulkan bahwa sejauh ini model pembiayaan murabahah belum memenuhi definisi dan pengertian murabahah berdasarkan prinsip syariah, yang menunjukkan ada persoalan terkait dengan kepatuhan prinsip syariah melalui akadmurabahah. ${ }^{6}$

Dalam membahas permasalahan hukum di atas, artikel ini akan menjelaskan terlebih dahulu apa saja yang menjadi prinsip syariah yang harus dipatuhi bagi LKS dalam menjalankan fungsi

2 Budiono, "Penerapan Prinsip Syariah", hlm. 57.

3 Lina Maulidiana, "Penerapan Prinsip-prinsip Murabahah dalam Perjanjian Islam”, Keadilan Progresif, 3, 2 (2012), hlm. 72.

4 Budiono, "Penerapan Prinsip Syariah", hlm. 64.

5 Sepky Mardian, "Tingkat Kepatuhan Syariah di Lembaga Keuangan Syariah”, Jurnal Akuntansi dan Keuangan Islam, 3, 1 (2015), hlm. 65.

6 Sugeng Widodo dan Nuhbatul Basyariah, "Telaah Kritis Implementasi Pembiayaan Murabahah pada Lembaga Keuangan Syariah Berdasarkan KDPPLKS”, At-Tauzi': Jurnal Ekonomi Islam, 20, 1 (2020): 13-22. 
intermediasinya. Kajian ini penting disampaikan karena prinsipprinsip inilah yang nantinya akan menjadi batu uji dalam menilai apakah fungsi intermediasi LKS di Indonesia telah mencerminkan kepatuhan syariah yang terdapat dalam hukum Islam. Pada bagian selanjutnya dibahas norma hukum tentang prinsip-prinsip syariah dalam kegiatan intermediasi LKS, yaitu sebagaimana yang tercantum dalam sejumlah Fatwa DSN-MUI, Peraturan Bank Indonesia, dan pada akad atau perjanjian yang dibuat LKS. Pembahasan norma hukum dari yang umum sampai khusus tersebut penting untuk melihat apakah ada kesinkronan dalam memahami prinsip-prinsip syariah. Pada bagian ketiga dibahas problematika kelembagaan pengawasan LKS dalam mematuhi prinsip-prinsip syariah. Artikel ditutup dengan penyampaian kesimpulan tentang sebab-sebab prinsip-prinsip syariah belum terintegrasi dengan baik, yaitu dilihat dari norma hukumnya dan kelembagaan pengawasannya.

\section{B. Etika Bisnis Islam dalam Fungsi Intermediasi Lembaga Keuangan Syariah}

Pada dasarnya LKS memiliki fungsi yang sama seperti lembaga keuangan konvensional, yaitu sebagai lembaga intermediasi. Lembaga intermediasi merupakan suatu lembaga yang mempertemukan antara masyarakat yang memiliki kelebihan dana yang tidak dipergunakan dan masyarakat yang kekurangan dana untuk memenuhi kebutuhannya. Fungsi LKS sebagai lembaga intermediasi dapat dilihat pada definisi LKS adalah suatu badan usaha atau institusi yang kegiatannya di bidang keuangan syariah dengan cara melakukan penghimpunan dana dan penyaluran dana kepada masyarakat, terutama dalam membiayai investasi pembangunan. ${ }^{7}$

Dalam menjalankan fungsi intermediasi, LKS diberikan keleluasaan untuk dapat melakukan transaksi bisnis untuk memenuhi kebutuhan hidup manusia dan mencapai kesejahteraan. Namun demikian, terdapat sejumlah batasan transaksi atau kegiatan bisnis

7 Ahmad Rodoni dan Abdul Hamid, Lembaga Keuangan Syariah (Jakarta: Penerbit Zikrul Hakim, 2008), hlm. 5. 
manakah yang dibenarkan atau dihalalkan dan tidak diperbolehkan atau diharamkan. Aturan-aturan tersebut merupakan perwujudan dari hukum Islam yang bertujuan untuk menjaga masyarakat dari transaksi yang bertentangan dengan tujuan hukum Islam. Bisnis dalam Islam tidak diperbolehkan mengandung beberapa hal, antara lain: ${ }^{8}$ pertama, maysir, yang secara harfiah bermakna judi atau transaksi yang tidak pasti dan mengandung sifat untung-untungan. Unsur maysir dilarang karena kegiatan transaksi bisnis yang dilakukan akan menimbulkan kerusakan jauh lebih besar daripada manfaatnya. Hal ini disebabkan karena transaksi bisnis yang mengandung unsur maysir bukanlah suatu kegiatan usaha yang produktif berupa kegiatan ekonomi dalam sektor riil yang berdampak pada peningkatan penawaran barang dan jasa, melainkan bentuk kegiatan yang menginginkan suatu keuntungan dengan mudah tanpa bekerja keras dan tanpa memikul tanggung jawab untuk memperoleh keuntungan. ${ }^{9}$

Prinsip kedua, gharar, ialah sesuatu yang tidak jelas atau disembunyikan oleh salah satu pihak dan perbuatan tersebut nantinya akan menyebabkan ketidakadilan bagi salah satu pihak yang bertransaksi bahkan menimbulkan bentuk perbuatan menganiaya. Gharar dilarang karena mengacu kepada ketidakpastian (uncertainty) atau hazard yang disebabkan ketidakjelasan berkaitan dengan objek perjanjian atau harga objek yang diperjanjikan di dalam transaksi. ${ }^{10}$ Pelarangan gharar bertujuan untuk mengedepankan transaksi yang transparan serta menghindari ketidakjelasan dalam berbisnis agar para pihak yang mejalankan bisnis memiliki pengetahuan yang cukup terhadap bisnis yang dijalankan serta mengetahui risiko yang dihadapi kedua belah pihak.

Prinsip ketiga, riba, ialah kelebihan yang diperoleh atas pertukaran antara dua atau lebih barang yang sejenis. Menurut Abu

8 Nurul Huda dan Mustafa Edwin Nasution, Investasi pada Pasar Modal Syariah (Jakarta: Kencana Prenadamedia, 2007), hlm. 29.

9 Sutan Remy Sjahdeini, Perbankan Syariah: Produk-produk dan Aspek-aspek Hukumnya (Jakarta: Kencana Prenadamedia, 2014), hlm. 171-172.

10 Sjahdeini, Perbankan Syariah, hlm.169. 
Hanifah, riba dianggap sebagai suatu perbuatan melebihkan harta yang berasal dari suatu transaksi yang sebenarnya dilarang untuk memberikan imbalan atau kompensasi dalam bentuk apapun. Hal ini berarti riba itu terkait tambahan berupa barang atau uang yang berasal dari suatu kegiatan atau transaksi pinjam meminjam uang atau utang piutang yang harus dilunasi sesuai dengan jatuh tempo yang disepakati. Termasuk ke dalam transaksi yang mengandung riba adalah yang menambahkan penghasilan atau pendapatan secara bathil seperti transaksi tukar menukar barang sejenis tetapi tidak terdapat kesamaan pada kualitas dan kuantitas barangnya, serta penyerahan barang tidak dilakukan bersamaan pada saat pertukaran barang tersebut. Begitu pula transaksi yang memberikan syarat akan memberikan kelebihan dari pokok pinjaman karena melewati batas waktu (nasi'ah).

Prinsip keempat, haram, yaitu segala perilaku yang dilarang untuk dilakukan di dalam Hukum Islam. Apabila perbuatan yang dilarang tersebut dilaksanakan tentu saja akan menjadi perbuatan yang tidak sah dan mendapat dosa. Prinsip kelima, bathil, ialah transaksi yang tidak sah sehingga transaksi tersebut menjadi batal. Dalam setiap bisnis dilarang melakukan transaksi secara bathil, seperti mengurangi kurang berat timbangan, mencampur menjadi satu sehingga pembeli sulit membedakan kualitas barang yang tidak layak di antara barang dagangan yang layak untuk mendapatkan keuntungan lebih banyak, menimbun atau sengaja menumpuk sejumlah barang, melakukan transaksi yang mengandung unsur penipuan atau melakukan upaya pemaksaan bahkan hingga ancaman. Tujuan dilarangnya transaksi bisnis yang bathil adalah sebagai upaya untuk mengurangi tansaksi bisnis yang akan banyak menimbulkan kerugian bagi berbagai pihak.

Sebagai lembaga intermediasi, LKS disebut M. Umar Chapra memiliki beberapa karakteristik. ${ }^{11}$ Pertama, LKS harus mampu meningkatkan kesejahteraan ekonomi masyarakat melalui kegiatan pembiayaan sektor riil yang memberikan kesempatan kerja secara luas

11 Andri Somitra, Bank dan Lembaga Keuangan Syariah (Depok: Kharisma Putra Utama, 2017), hlm. 22. 
bagi masyarakat yang membutuhkan, sehingga laju pertumbuhan ekonomi akan tumbuh secara optimal. LKS harus memperhatikan konsep kesejahteraan ekonomi dalam sistem ekonomi Islam, bukan pada seberapa tinggi pertumbuhan ekonomi itu sendiri. Sebab, sistem ekonomi yang dijalankan berupaya untuk menerapkan, antara lain kesejahteraan material melalui kegiatan produksi barang dan jasa yang tidak bertentangan dengan prinsip syariah. LKS juga harus mampu mempersempit jurang antara yang mereka yang kurang mampu dan yang mampu melalui kegiatan penyaluran dana. Ini berarti LKS harus mampu memperhatikan pemerataan dalam pertumbuhan ekonomi. Selain itu LKS dalam melakukan penyaluran dana tidak boleh melakukan kegiatan pembiayaan ke kegiatan usaha yang dapat merusak lingkungan hidup dan sumber daya alam yang dapat menimbulkan bahaya berupa minimnya sumber daya alam dan lingkungan yang akan digunakan oleh generasi sekarang atau generasi mendatang.

Kedua,LKS harusmemperhatikan keadilan sosial ekonomi dalam melakukan kegiatan pendistribusian kekayaan dan pendapatan, agar tercapai tujuan pemerataan ekonomi di setiap lapisan masyarakat. Ketiga, LKS harus mampu melakukan kegiatan mobilisasi tabungan melalui kegiatan investasi untuk pembangunan perekonomian dengan cara yang adil. Karena itu, LKS dapat memberikan bagi hasil yang dapat dirasakan oleh setiap pihak yang bersangkutan. Mobilisasi tabungan sangat penting untuk mewujudkan tujuan sosial ekonomi. Sebab, tabungan yang dihimpun oleh LKS harus menjadi dana yang produktif bagi kesejahteraan rakyat. Oleh karenanya LKS harus mampu memberikan literasi pemahaman ke masyarakat penyetor dana mengenai konsep harta dalam Islam yang sangat melarang perbuatan menumpuk harta yangtidak produktif. Keempat, LKS harus mampu mengoptimalkan zakat, infak dan sadaqah. Dalam konsep keuangan Islam, LKS merupakan suatu lembaga yang berfungsi sebagai baitul maal (lembaga penghimpun dan penyalur dana-dana sosial) dan baitul tamwil (lembaga penghimpun dan penyalur dana pembiayaan yang bersifat profit atau menguntungkan).

Fungsi intermediasi yang dilakukan oleh LKS sebagai badan 
usaha adalah menjalankan bidang keuangan berdasarkan prinsipprinsip akad dalam hukum Islam. Ini menunjukkan setiap ketentuanketentuan mengenai perjanjian dalam Islam merupakan norma hukum yang mengatur dan harus dipatuhi dan diterapkan dalam kegiatan LKS. Norma hukum Islam mengenai lembaga keuangan menurut ushul fiqh merupakan hasil pengembangan akad-akad muamalah yang ada di dalam hukum Islam, yang penerapannya selalu mendasarkan pada prinsip-prinsip syariah. Norma-norma hukum Islam tentang akad-akad muamalah merupakan norma yang mengatur akad-akad dalam segala kegiatan transaksi bisnis baik yang dilakukan oleh perseorangan maupun LKS. ${ }^{12}$

Fungsi intermediasi yang dimiliki oleh LKS lebih bervariasi dibandingkan fungsi intermediasi lembaga keuangan konvensional. Hal ini dikarenakan sistem memperoleh keuntungan pada LKS terdiri dari berbagai macam, antara lain: sistem pembagian hasil baik berupa keuntungan ataupun kerugian (profit and loss sharing), selisih harga jual dan beli (profit margin), serta keuntungan melalui pemberian biaya (fee). ${ }^{13}$ Berbagai macam sistem memperoleh keuntungan tersebut mengakibatkan akad-akad yang dilakukan oleh setiap LKS menurut prinsip-prinsip syariah akan beragam, dan penggunaan akad-akadnya akan menjadi pilihan nasabah sesuai dengan kebutuhan dan tujuan yang ingin diperoleh nasabah LKS. Nasabah yang menginginkan uang atau dananya disimpan dengan aman dan tidak terkena risiko apa pun maka kepadanya dapat diberikan produk LKS berupa

12 Hafidz Abdurrahman, Ushul Fiqih: Membangun Paradigma Berfikir Tasyri'i (Bogor: Penerbit Al-Azhar Press, 2003), hlm. 30.

13 Pasal 1 Angka 13 Undang-Undang Nomor 10 Tahun 1998 tentang Perubahan Atas Undang-Undang Nomor 7 Tahun 1992 tentang Perbankan: "Prinsip Syariah adalah aturan perjanjian berdasarkan hukum Islam antara bank dengan pihak lain untuk menyimpan dana dan atau pembiayaan kegiatan usaha, atau kegiatan lainnya yang dinyatakan sesuai dengan syariah, antara lain pembiayaan berdasarkan prinsip bagi hasil (mudharabah), pembiayaan berdasarkan prinsip penyertaan modal (musharakah), prinsip jual beli barang dengan memperoleh keuntungan (murabahah), atau pembiayaan barang modal berdasarkan prinsip sewa murni tanpa pilihan (ijarah), atau dengan adanya pilihan pemindahankepemilikan atas barang yangdisewa dari pihak bank oleh pihak lain (ijarah wa iqtina)". 
simpanan (giro atau atau tabungan) yang berdasarkan prinsip titipan (wadi'ah), sedangkan apabila nasabah yang menginginkan uang atau dananya disimpan untuk mendatangkan manfaat secara ekonomi maka kepadanya dapat diberikan produk LKS berupa simpanan yang diikat atau didasarkan pada prinsip bagi hasil yang berdasarkan prinsip mudharabah.

LKS akan menerima dana atau menghimpun dana dari masyarakat atau nasabah melalui berbagai jenis, antara lain berupa tabungan, deposito atau investasi, dan giro. Setelah terhimpun dana dari masyarakat atau nasabah maka LKS akan menyalurkannya melalui kegiatan pembiayaan di sektor riil dengan tujuan produktif menggunakan trade-based financing dan investment-based financing. Pola trade-based financing merupakan pola jual beli dan sewa, sedangkan investment-based financing merupakan pola bagi hasil. Selain itu, LKS dapat pula memberikan dana talangan dengan pola pinjaman. ${ }^{14}$

Semua pembiayaan dalam LKS akan diikat dengan berbagai akad pembiayaan, antara lain pembiayaan dengan basis transaksi trade-based financing. Pembiayaan ini terdiri dari dua jenis transaksi, yaitu: pertama, pembiayaan dengan pola jual beli dengan cara melakukan tukar menukar harta antara dua pihak atas dasar kesepakatan dengan imbalan pada sesuatu yang diperkenankan dengan menggunakan beberapa akad antara lain: murabahah, salam, dan istishna. Kedua, pembiayaan dengan pola sewa atau transaksi sewa dengan menyertakan imbalan yang dilakukan atas dasar suatu manfaat dengan imbalan jasa. Pada pola demikian biasanya akad yang digunakan ijarah dan ijarah muntahiyyah bi tamlik.

Bentuk penyaluran dana lainnya adalah dengan pembiayaan menggunakan pola investment-based financing. Pola ini merupakan pembiayaan dengan pola bagi hasil yang dilakukan dengan cara kemitraan antara dua pihak, yaitu pemilik modal dan pengelola usaha. Akad yang biasa digunakan adalah mudharabah atau musyarakah. Selain kedua pola yang telah disebutkan, penyaluran dana pada LKS juga dapat dilakukan dengan pola pembiayaan dengan talangan. Pola

14 Darsono, dkk., Perbankan Syariah di Indonesia: Kelembagaan dan Kebijakan serta Tantangan ke Depan (Jakarta: Rajawali Press, 2017), hlm. 56-65. 
pembiayaan dengan talangan merupakan pembiayaan dengan pola pinjaman dengan menggunakan akad qardh.

Berbagai uraian di atas menunjukkan LKS sebagai lembaga yang menjalankan fungsi intermediasi secara luas dan beragam dengan berbagai akad. Karena itu LKS harus memperhatikan berbagai macam varian ketentuan-ketentuan yang berkaitan dengan segala hak dan kewajiban antara nasabah dan LKS, termasuk memperhatikan jenis tanggung jawab para pihak yang timbul dari setiap jenis akad atau perjanjian. LKS harus mampu menyesuaikan kebutuhan pendanaan bagi nasabah sebagaimana yang telah disepakati dengan ketentuanketentuan dalam prinsip syariah, baik berupa akad atau perjanjian trade-based financing, investment-based financing, maupun pembiayaan dengan talangan, termasuk pula jasa perbankan. LKS juga harus memenuhi kewajiban sebagai penyedia dana dan barang sesuai yang telah disepakati dalam besar, jumlah, nominal, dan kriteria. Hal ini harus dilakukan LKS sebagai bentuk pemenuhan tangung jawab LKS pada nasabah. Nasabah pun tidak lepas dari berbagai kewajiban yang harus dipenuhi sebagai tanggung jawab dari adanya akad atau perjanjian yang telah dibuat dengan LKS. Menjadi suatu keharusan dalam perjanjian selain mencantumkan hak dan kewajiban juga mencantumkan tanggung jawab sesuai prinsip syariah.

Fungsi intermediasi LKS yang menghimpun dana yang dititipkan nasabah dan menyalurkannya untuk memperoleh keuntungan harus mendasarkan pada adanya underlying transaction dan/atau underlying asset sebagai alas untuk bertransaksi di LKS. Berdasar skema akad itulah kehalalan transaksi atau sering disebut juga kesyariahan produk menjadi dapat dipertanggungjawabkan. Dengan demikian, fungsi intermediasi LKS sangat berkaitan erat dengan karakteristik dari produk keuangan syariah berbasis sektor riil, yang dalam setiap transaksinya harus didasarkan pada riil asset (ada underlying assetnya). ${ }^{15}$

15 Fathurrahman Djamil, "Pengembangan dan Inovasi Produk Lembaga Keuangan Syariah di Indonesia (Kajian Transaksi Berbasis Syariah dan Hukum Positif)", Kordinat: Jurnal Komunikasi Antar Perguruan Tinggi Agama Islam, 15, 2 (2016), hlm. 147-148. 


\section{Prinsip-Prinsip Syariah dalam Kegiatan Intermediasi oleh Lembaga Keuangan Syariah}

Dari uraian mengenai fungsi intermediasi LKS dalam etika bisnis Islam pada bagian sebelumnya, maka fungsi intermediasi LKS dalam berbagai pembiayaan dengan mengikuti bermacam-macam pola akad syariah, menempatkan LKS dapat melakukan bisnis praktis tidak hanya sebatas menyalurkan dana yang dibutuhkan masyarakat. Oleh karenanya seharusnya dalam peran dan kedudukan LKS dalam menjalankan fungsi intermediasi tidak hanya menempatkan LKS sebagai lembaga penyalur kredit.

Fungsi intermediasi LKS yang beragam harus patuh pada apa yang menjadi prinsip-prinsip syariah dalam intermediasi LKS yang ditetapkan dalam hukum Islam. Prinsip-prinsip syariah berkaitan dengan fungsi intermediasi LKS di Indonesia adalah segala prinsipprinsip yang telah ditetapkan oleh Dewan Syariah Nasional-Majelis Ulama Indonesia (DSN-MUI), sebagaimana ketentuan Pasal 1 angka 12 Undang-Undang Nomor 21 Tahun 2008 tentang Perbankan Syariah (UU Perbankan Syariah). Lebih lanjut pada Pasal 1 angka 13 disebutkan, setiap akad atau perjanjian yang dibuat oleh LKS harus mendasarkan pada prinsip syariah, dan tentunya prinsip syariah yang dimaksud adalah prinsip syariah. Persoalannya adalah, sekalipun UU Perbankan Syariah telah memberikan legitimasi bagi DSN-MUI menetapkan prinsip syariah yang diberlakukan bagi LKS, isi darifatwafatwa tersebut masih berisikan ketentuan-ketentuan yang abstrak. Materi muatan fatwa hanya memberikan pertimbangan suatu akad menjadihalal atau haramjika mengandungunsur-unsuryangdilarang, namun tidak terdapat ketentuan apa saja yang mengandung unsur halal dan haram tersebut. Inilah yang mengakibatkan fatwa-fatwa tersebut masih harus ditafsirkan lebih lanjut oleh stakeholder. Tentu saja ini akan berdampak pada banyak tafsiran antar pihak. Terlebih lagi DSN-MUI dalam sistem ketatanegaraan Indonesia bukanlah lembaga negara yang memiliki kewenangan megeluarkan peraturan, sehingga penuangan lebih lanjut muatan fatwa-fatwa dilakukan oleh lembaga-lembaga atau stakeholder berwenang, misalnya Peraturan 
Bank Indonesia, Peraturan Otoritas Jasa Keuangan, dan lain-lain yang terkait dengan kegiatan lembaga keuangan. Penuangan lebih lanjut muatan fatwa-fatwa tersebut akan ditafsirkan sesuai pemahaman tiap lembaga, yang nantinya akan diterapkan ke semua LKS.

Dalamkonteks Indonesia, sesuai dengan yang telah dikemukakan sebelumnya, beberapa prinsip syariah telah dituangkan dalam Fatwa DSN-MUI. Fatwa yang ditetapkan oleh DSN-MUI kemudian menjadi pendapat hukum yang digunakan oleh sejumlah stakeholder. Fatwa sendiri merupakan sebuah respons ulama berupa penjelasan dalam bentuk keputusan hukum terhadap masalah yang dihadapi masyarakat. Dasar hukum yang digunakan dalam mengahsilkan fatwa adalah Al-Quran, Hadits, dan pemikiran para ulama (ijtihad, ijma' dan qiyas). Dengan kata lain dapat dikataka, fatwa merupakan legal opinion yang dihasilkan melalui suatu kegiatan penalaran yang dilakukan oleh para ulama dengan maksud dan tujuan untuk menjawab suatu permasalahan.

Di Indonesia, pembuatan Fatwa DSN-MUI yang diberlakukan untuk LKS harus sesuai dengan pedoman yang telah ditetapkan, yaitu Pedoman Penetapan Fatwa MUI Nomor U-596/MUI/X/1997 tanggal 2 Oktober 1997. Pedoman ini dibuat oleh Komisi Fatwa MUI. Dalam Pedoman ini disebutkan, "setiap masalah yang dibahas di Komisi Fatwa (termasuk fatwa tentang ekonomi syariah) harus didasarkan pada Al-Quran, Sunnah/Hadits, Ijma’ dan Qiyas. Sebelum fatwa ditetapkan hendaklah ditinjau terlebih dahulu secara seksama pendapat para imam mazhab tentang masalah yang akan difatwakan tersebut berikut dalil-dalilnya." ${ }^{16}$ Dari penjelasan ini diketahui bahwa setiap Fatwa yang dibuat oleh DSN-MUI bagi LKS pada dasarnya telah berupaya semaksimal mungkin memenuhi prinsip-prinsip syariah. Setiap jenis traksaksi dalam berbagai akad syariah yang akan diberlakukan bagi LKS tentunya telah sesuai dengan prinsip-prinsip umum syariah.

Namun, bagaimanakah kesesuaian berbagai Fatwa tersebut dengan prinsip-prinsip syariah. Beberapa pola-pola penyerapan jenis-

16 M. Cholil Nafis, Teori Hukum Ekonomi Syariah (Jakarta: UI Press, 2011), hlm. 77. 
jenis transaksi LKS yang telah dimuat ke dalam beberapa Fatwa yang dibuat oleh DSN-MUI antara lain, pertama, fatwa yang terkait dengan kegiatan penghimpunan dana, yaitu giro syariah (Fatwa Nomor 1/DSN-MUI/IV/2000); tabungan syariah (Fatwa Nomor 2 / DSN-MUI/IV/2000); dan deposito syariah (Fatwa Nomor 3/DSN$\mathrm{MUI} / \mathrm{IV} / 2000$ ).

Kedua, fatwa terkait kegiatan penyaluran dana, yaitu transaksi melalui akad mudharabah (Fatwa Nomor 7/DSN-MUI/IV/2000); transaksi melalui akad musyarakah (Fatwa Nomor 8/DSN-MUI/ IV/2000); transaksi melalui akad murabahah (Fatwa Nomor 4/ DSN-MUI/IV/2000). Ketiga, fatwa terkait kegiatan pelayanan jasa, antara lain penukaran valuta asing (sharf) (Fatwa Nomor 28/DSNMUI/III/ 2002); transaksi Letter of Credit (L/C) impor syariah (Fatwa Nomor 34/DSN-MUI/IX/2002); dan kegiatan mengenai Bank Garansi Syariah (Fatwa Nomor 11/DSN-MUI/IV/2000).

Pada dasarnya sifat mengatur dalam fatwa yang dikeluarkan oleh DSN-MUI berupa ketentuan-ketentuan yang bersifat memberikan pertimbangan. Ini artinya, rumusan dalam fatwa-fatwa tersebut merupakan pedoman umum yang harus dituangkan lebih lanjut ke dalam berbagai kebijakan atau peraturan yang berlaku bagi setiap kegiatan transaksi LKS. Untuk lebih jelasnya, sebagai contoh, ketentuan dalam Fatwa Nomor 4/DSN-MUI/IV/2000 tentang Murabahah akan diuraikan dalam Tabel 1.

Rumusan fatwa sebagaimana dalam Tabel 1 terlihat lebih mengatur hal yang umum dan tidak bersifat operasional. Karena itu, pada saat LKS akan membuat akad-akad syariah dengan menggunakan Fatwa tersebut, masih harus menafsirkan transaksi yang berkaitan dengan fatwa bagaimanakah yang tidak melanggar prinsip syariah. ${ }^{17}$ Di samping itu, struktur dan format Fatwa juga sebatas menentukan dasar atau status hukum dari suatu transaksi yang dimintakan fatwanya, serta menentukan kemungkinan kegiatan seperti apa yang halal dan haram. Dengan begitu, sifat dari fatwa masih

17 Hamli Syaifullah, "Penerapan Fatwa DSN-MUI tentang Murabahah di Bank Syariah”, Kordinat: Jurnal Komunikasi Antar Perguruan Tinggi Agama Islam, 17, 2 (2018), hlm. 274. 
Tabel 1. Fatwa DSN-MUI tentang Murabahah

\begin{tabular}{|c|c|}
\hline Ketentuan Umum & Ketent \\
\hline $\begin{array}{l}\text { - LKS dan nasabah harus melakukan } \\
\text { akad murabahah yang bebas riba; } \\
\text { - Barang yang diperjualbelikan tidak } \\
\text { diharamkan oleh syariat Islam; } \\
\text { - LKS membiayai sebagian atau seluruh } \\
\text { harga pembelian barang yang telah } \\
\text { disepekati kualifikasinya; } \\
\text { - LKS membeli barang yang diperlukan } \\
\text { nasabah atas nama LKS sendiri dan } \\
\text { pembelian ini harus sah dan bebas } \\
\text { riba; } \\
\text { - LKS harus menyampaikan semua hal } \\
\text { yang berkaitan dengan pembelian, } \\
\text { misalnya jika pembelian dilakukan } \\
\text { secara utang; } \\
\text { - LKS kemudian menjual barang } \\
\text { tersebut kepada nasabah (pemesan) } \\
\text { dengan harga jual senilai harga beli } \\
\text { pluskeuntungannya. Dalam kaitan ini } \\
\text { LKS harus memberitahu secara jujur } \\
\text { harga pokok barang kepada nasabah } \\
\text { berikut biaya yang diperlukan; } \\
\text { - Jika LKS hendak mewakilkan kepada } \\
\text { nasabah untuk membeli barang dari } \\
\text { pihak ketiga, akad jual beli murabahah } \\
\text { harus di lakukan setelah barang } \\
\text { secara prinsip menjadi milik LKS. }\end{array}$ & $\begin{array}{l}\text { - Nasabahmengajukanpermohonan } \\
\text { dan perjanjian pembelian suatu } \\
\text { barang atau aset kepada LKS; } \\
\text { - Jika LKS menerima permohonan } \\
\text { tersebut, ia harus membeli terlebih } \\
\text { dahulu aset yang dipesannya secara } \\
\text { sah dengan pedagang; } \\
\text { - LKS kemudian menawarkan aset } \\
\text { tersebut kepada nasabah dan } \\
\text { nasabah membeli sesuai dengan } \\
\text { perjanjianyangtelahdisepakatinya, } \\
\text { karena secara hukum perjanjian } \\
\text { tersebut mengikat, kemudian } \\
\text { kedua belah pihak harus membuat } \\
\text { kontrak jual beli; } \\
\text { - Jaminan dalam murabahah } \\
\text { diperbolehkan, agar nasabah serius } \\
\text { dengan pesanannya. Di sini LKS } \\
\text { dapat meminta nasabah untuk } \\
\text { menyediakan jaminan yang dapat } \\
\text { dipegang. }\end{array}$ \\
\hline
\end{tabular}

berupa ifadah 'ilmiah, yaitu suatu upaya memberikan ilmu pengetahuan dalam rangka mencerahkan wawasan saja mengenai transaksi yang dilakukan. Fatwa-fatwa tersebut masih harus ditafsirkan kembali oleh dewan pengawas yang berada di setiap LKS. Oleh karenanya memang fatwa-fatwa yang dibuat oleh DSN-MUI mengenai kegiatan ekonomi keuangan yang dijalankan di LKS belum sepenuhnya dipatuhi oleh kalangan-kalangan pemangku kebijakan dari LKS yang kapasitasnya memang bukan merupakan seorang ulama ekonomi syariah. ${ }^{18}$

18 Tuti Hasanah, "Transformasi Fatwa Dewan Syariah Nasional ke dalam Hukum Positif”, Syariah: Jurnal Hukum dan Pemikiran, 16, 2 (2016), hlm. 164. 
Inti dari fatwa yang dikeluarkan oleh DSN-MUI adalah memberi rambu-rambu bagi LKS agar tidak melenceng dari prinsip syariah yang menjadi etika bisnis Islam. Namun Fatwa DSN-MUI sendiri masih sulit diterapkan karena aturannya yang masih umum dan tidak operasional. Menurut M. Atho Mudzhar dkk., hal ini dikarenakan metode ijtihad para ulama di DSN-MUI pada saat mengeluarkan fatwa masih terbebani oleh kutub ulama salafi dan kutub ulama kontemporer. Oleh karenanya memang metode penetapan Fatwa DSN-MUI belum bersifat operasional. Inilah yang harus lebih diperhatikan oleh DSN-MUI dalam menetapkan suatu fatwa agar senantiasa dapat mempertimbangkan kemaslahatan secara umum (mashalih al'ammah) namun tetap sesuai dengan tujuan dari adanya syariah atau maqashid syariah. ${ }^{19}$

Berkaitan dengan anggapan Fatwa DSN-MUI tidak memiliki kekuatan hukum yang mengikat seperti halnya peraturan, disebabkan DSN-MUI tidak termasuk salah satu dari lembaga yang diatur dalam Pasal 8 Undang-Undang Nomor 12 Tahun 2011 tentang Pembentukan Peraturan Perundang-Undangan. ${ }^{20}$ Karena itu, implementasi Fatwa agar implementatif masih membutuhkan tindak lanjut, antara lain dari pemerintah. Tindak lanjut ini tentu juga akan disertai penafsiran pemerintah terhadap isi fatwa. Misal, Peraturan Bank Indonesia Nomor 10/16/PBI/ 2008 tentang Pelaksanaan Prinsip Syariah dalam Kegiatan Penghimpunan Dana dan Penyaluran Dana serta Pelayanan Jasa Bank Syariah. Dalam Peraturan ini, fungsi intermediasi LKS ditafsirkan sama seperti halnya penyaluran dana dalam bentuk pembiayaan dengan kredit. Penyamaannya dapat dilihat pada ketentuan Pasal 1 angka 8, “...pembiayaan merupakan penyediaan dana atau tagihan yang dapat dipersamakan dengan itu." ${ }^{21}$

Peraturan Bank Indonesia yang menyangkut kegiatan

19 M.Atho Mudzhar,dkk., Fatwa Majelis Ulama Indonesia dalam Perspektif Hukum dan Perundang-Undangan(Jakarta: Badan Libang dan Diklat Kementerian Agama, 2012), hlm. 318.

20 Abdurrahman Raden Aji Haqqi, "Shariah Governance in Islamic Financial Institution: An Appraisal”, US-China Law Review, 11 (2014), hlm. 118.

21 Peraturan Bank Indonesia Nomor 10/16/PBI/2008tentang Pelaksanaan Prinsip Syariah dalam Kegiatan Penghimpunan Dana dan Penyaluran Dana serta Pelayanan Jasa Bank Syariah, Pasal 1 angka 8. 
pembiayaan syariah di LKS juga tidak memasukkan Fatwa DSNMUI sebagai bagian konsideran mengingat ataupun menimbang. Salah satunya adalah Peraturan Bank Indonesia Nomor 10/16/ PBI/2008. Kedudukan Fatwa DSN-MUI sendiri dalam UU Nomor 12 Tahun 2011 memang bukanlah termasuk peraturan perundangundangan. Namun beberapa substansi yang dirumuskan dalam berbagai peraturan BI maupun OJK ada yang merujuk Fatwa DSNMUI, terutama hal yang menyangkut nama pembiayaan, tetapi juga banyak yang tidak dan hanya merujuk pada peraturan atau ketentuan yang berlaku bagi transaksi dalam lembaga keuangan konvensional, yang sebenarnya tidak tepat diberlakukan terhadap LKS.

Selain itu fatwa DSN-MUI yang bersifat menghimbau tersebut nyatanya masih belum mengatur secara tegas mengenai LKS yang dalam kegiatan pembiayaan dengan sistem bagi hasil yang masih enggan menempatkan asetnya karena LKS menghadapi kendala berupa persoalan moral hazard dalam transaksinya. Dengan belum diaturnya secara tegas dalam Fatwa DSN-MUI mengenai hal tersebut ditambah dengan praktik dalam transaksi pembiayan dengan sistem bagi hasil ini, LKS tampaknya masih kesulitan untuk benar-benar mengetahui pula secara pasti tentang laba usaha yang dihasilkan oleh nasabah penerima pembiayaan. ${ }^{22}$ Bagian inilah yang kerap justru menghasilkan suatu kebijakan yang serupa dengan kegiatan kredit pada bank konvensional.

Salah satu praktik pembiayaan LKS yang tidak tepat menafsirkan FatwaDSN-MUImengenaipembiayaan murabahahadalah penawaran batas pembiayaan atau pokok pembiayaan yang dapat diangsur oleh nasabah yang bermaksud melakukan kegiatan pembiayaan. Ini berarti penawaran pembiayaan yang dilakukan oleh LKS bukan berupa barang-barang yang dapat dibeli oleh nasabah dengan model pembiayaan murabahah. Hal ini bisa jadi disebabkan LKS memang tidak benar-benar memiliki barang-barang tersebut, sehingga LKS dengan nasabah dalam praktik murabahah bukanlah transaksi jual beli barang melainkan jual beli uang. Praktik demikian merupakan

22 M. Ali Mansyur, "Aspek Hukum Perbankan Syariah dan Implementasinya di Indonesia”, Jurnal Dinamika Hukum, 11, edisi khusus (2011), hlm. 71. 
hasil tafsiran LKS yang keliru, akibat abstraknya ketentuan dalam Fatwa DSN-MUI. ${ }^{23}$

Untuk itulah upaya integrasi etika bisnis Islam sebagai kepatuhan syariah dalam berbagai regulasi yang mendukung LKS sebagai intermediasi dengan sistem syariah perlu dioptimalkan melalui pembuatan regulasi di tingkat stakeholder LKS. Hal ini bisa ditempuh misalnya dengan pembuatan Standar Operasional Produk (SOP) terhadap berbagai macam pembiayaan melalui berbagai macam akad yang bersifat teknis dan sesuai dengan prinsip syariah. Selain itu perlu pula didukung berbagai macam regulasi yang mendukung LKS untuk menggiatkan kegiatan bagi hasil dan profit margin sesuai sistem syariah yang saat ini masih menjadi persoalan bagi LKS dalam melakukan pembiayaan institusional melalui sistem bagi hasil dan profit margin.

\section{Problematika Kelembagaan Pengawas Kepatuhan Prinsip Syariah}

Sebagai suatu lembaga yang menjalankan fungsi intermediasi, LKS harus mampu pula menjalankan fungsi-fungsi tersebut dalam upaya pemenuhan tujuan kegiatan ekonomi sebagai rahmatan lil 'alamin. Fungsi intermediasi dalam hal ini tidak hanya dimaknai sebagai mempertemukan antara nasabah atau masyarakat kelebihan dana dan nasabah atau masyarakat yang membutuhkan dana. Lebih dari itu, LKS dan nasabah sebenarnya sedang membangun suatu kerjasama peningkatan kesejahteraan secara bersama-sama. Kedudukan nasabah penyetor dana dan LKS bukan lantas menjadi lebih tinggi daripada nasabah yang membutuhkan dana, melainkan ketiga pihak tersebut merupakan rantai kerjasama yang saling berkaitan dan setara satu sama lainnya. Inilah sebenarnya prinsip utama pembeda LKS dengan lembaga keuangan konvensional. Kesetaraan kedudukan antar pihak merupakan perwujudan dari asas kesetaraan (al-musawah). Dalam hal ini LKS dipercaya masyarakat untuk mampu menjalankan fungsinya

23 Abdul Latief, "Implementasi Fatwa DSN-MUI terhadap Praktik Pembiayaan Murabahah Bank Syariah Mandiri dan Bank Muamalat KCP Ponorogo”, Muslim Heritage, 1, 1 (2016), hlm. 5. 
mencapai konsep rahmatan lil 'alamin dan menjaga kehalalan dalam setiap produknya, dan karenanya diharuskan mematuhi prinsip syariah dalam core business yang diselenggarakannya.

Berkaitan dengan kepatuhan pada prinsip syariah tersebut, persoalan terkait kelembagaan terutama pada pengawasan tampaknya turut menyebabkan kepatuhan belum efektif. Dari struktur kelembagaan, setiap LKS baik yang berbentuk Perseroan Terbatas (PT) ataupun Koperasi, diwajibkan memiliki sekurang-kurangnya tiga orang Dewan Pengawas Syariah (DPS). DPS ini berfungsi melakukan pengawasan setiap kegiatan atau transaksi syariah yang dilakukan LKS. ${ }^{24}$ Kewajiban menghadirkan DPS dalam setiap LKS ini dapat dilihat, antara lain Pasal 32 UU Perbankan Syariah, Pasal 109 Undang-Undang Nomor 40 Tahun 2007 tentang Perseroan Terbatas, dan Surat Keputusan Nomor 16/Per/M.KUM/IX/2015 tentang Pelaksanaan Kegiatan Usaha Simpan Pinjam dan Pembiayaan Syariah oleh Koperasi.

Dalam tata kelola LKS, kedudukan DPS memiliki kesamaan dengan istilah hisbah pada masyarakat muslim tradisional atau klasik. Kesamaannya terletak pada tujuan dan fungsi hisbah dan DPS, yaitu sama-sama berupaya untuk mendorong kegiatan muamalah masyarakat sesuai dengan prinsip-prinsip syariah. Begitu pula dengan kedudukan DPS pada masyarakat muslim modern, yang dikenal dengan muhtasib, yang menempatkan DPS atau muhtasib menjalankantugaspemberiannasehat (advisory) danmelakukanfungsi pengawasan (supervisory) sehingga kegiatan yang diselenggarakan patuh atau sesuai dengan prinsip syariah. ${ }^{25}$ Ini menunjukkan bahwa DPS merupakan unsur yang sangat penting dalam tata kelola LKS

24 Karena itu, DPS merupakan lembaga pengawasan dalam institusi perbankan, yang dibedakan dari lembaga pengawasan dalam level nasional. Dalam level nasional, pengawasan dilakukan oleh DSN, yang sesungguhnya bukan badan pemerintah melainkan bagian dari MUI. Agus Triyanta, "Implementasi Kepatuhan Syariah dalam Perbankan Islam (Syariah) (Studi Perbandingan antara Malaysia dan Indonesia)", Jurnal Hukum Ius Quia Iustum, 16, edisi khusus (2009), hlm. 219-220.

25 Isra, Islamic Financial System: Principles and Operations (Kuala Lumpur: Isra, 2010), hlm. 703. 
guna menjalankan kegiatan yang sesuai dengan prinsip syariah.

Kedudukan DPS yang sangat vital dalam kegiatan suatu LKS nyatanya kerap tidak efektif. Secara regulasi memang kedudukan dan fungsi DPS telah diatur dalam Peraturan Bank Indonesia Nomor 6/24/PBI/2004. Pada PBI tersebut DPS melakukan pengawasan pada tingkatan internal LKS. Kedudukan DPS sebagai pengawas internal LKS adalah setara dengan kedudukan direksi LKS. Dengan demikian, hubungan antara DPS dan direksi LKS dalam suatu struktur organisasi LKS bersifat koordinatif, di mana seorang DPS berhak dan berwenang memberikan nasehat dan masukan kepada direksi LKS mengenai kegiatan atau transaksi LKS berdasarkan prinsip syariah. Kesetaraan kedudukan DPS dan direksi LKS dalam suatu LKS ini menimbulkan konsekuensi pula bahwa DPS di dalam internal LKS sebagai perusahaan berada di bawah Dewan Komisaris dan Para Pemegang Saham. Gambaran struktur organisasi semacam ini menyulitkan bagi DPS untuk melaksanakan fungsinya sebagai advisory dan supervisory. Sebab, pertimbangan dan masukan DPS terhadap kegiatan atau transaksi LKS harus menyesuaikan pula kebutuhan pemegang saham dan dewan komisaris untuk mengejar profit sebesar-besarnya, yang pada praktiknya akan mendorong DPS sebagai pihak yang hanya turut memenuhi kepentingan pihak tersebut. ${ }^{26}$

Persoalan lain terkait kelembagaan pengawasan pada LKS adalah rangkap jabatan seorang DPS dalam beberapa LKS. Hal ini sebenarnya telah diatur dalam Surat Edaran Bank Indonesia (SEBI) Nomor 12/13 / DPbS / 2010, bahwa seorang anggota DPS hanya dapat merangkap jabatan sebagai DPS tidak lebih dari empat LKS, dengan perincian maksimal menjadi DPS di dua LKS berjenis bank dan dua LKS non-bank. Seorang DPS juga dilarang menjadi konsultan di lembaga keuangan lain di luar empat LKS tersebut. Namun demikian, kebolehan rangkap jabatan ini justru dapat menimbulkan masalah,

26 Ascarya, "Comparing Islamic Banking Development in Malaysia and Indonesia: Lessons for Instruments Development”, makalah dalam Diskusi Periodik Directorate of Monetary Management Bank Indonesia, Jakarta, $27 / 1 / 2006$, hlm. 30 . 
yaitu keputusan atau masukan DPS menjadi bias di kesemua LKS yang diawasinya. Bias tersebut terjadi karena DPS kerap memberi pertimbangan yang sama untuk semua transaksi LKS tanpa melihat karakteristik dan kebutuhan yang berbeda pada tiap transaksi antar LKS.

Selain itu, persoalan lainnya dalam kelembagaan pengawasan LKS adalah dibolehkannya anggota DSN-MUI menjadi anggota DPS. Hal ini justru menyebabkan terjadinya rangkap pada fungsi pengawasan seorang anggota DSN-MUI dan DPS. Padahal fungsi pengawasan yang dilakukan oleh anggota DSN-MUI adalah sebagai lembaga pengawas eksternal LKS, sementara pengawasan DPS lebih ke internal. Karena itu akan potensial terjadi bias hasil pengawasan internal dan eksternal. Keanggotaan secara ganda anggota DSN-MUI dan sekaligus anggota DPS, dapat menimbulkan masalah mengenai kemandirian antar fungsi kedua lembaga pengawas tersebut. Sebab, menurut PBI Nomor 6/24/PBI/2004, ${ }^{27}$ seorang anggota DPS pada suatu LKS memiliki kewajiban melakukan kegiatan pemberian laporan hasil pengawasan terkait dengan pelaksanaan prinsip syariah pada suatu LKS kepada DSN-MUI secara periodik. Dapat dibayangkan bila seorang anggota DSN merangkap menjadi DPS pada suatu LKS, akan terjadi conflict of interest terhadap hasil pemeriksaan laporan tersebut dan hal ini akan menimbulkan pula ketiadaan fungsi check and balances dalam kegiatan LKS.

Selain persoalan rangkap jabatan, persoalan terkait tidak adanya regulasi yang mengatur pengujian kompetensi DPS turut memberi andil bagi ketidakberdayaan LKS menyesuaikan diri sepenuhnya dengan prinsip syariah. Kompetensi DPS di Indonesia lebih banyak

27 Pasal 27 ayat (1) Peraturan Bank Indonesia Nomor 6/24/PBI/ 2004: "Tugas, wewenang, dan tanggung jawab DPS antara lain meliputi: (a) memastikan dan mengawasi kesesuaian kegiatan operasional bank terhadap fatwa yang dikeluarkan oleh DSN; (b) menilai aspek syariah terhadap pedoman operasional, dan produk yang dikeluarkan bank; (c) memberikan opini dari aspek syariah terhadap pelaksanaan operasional bank secara keseluruhan dalam laporan publikasi bank; (d) mengkaji produk dan jasa baru yang belum ada fatwa untuk dimintakan fatwa kepada DSN; dan(e) menyampaikan laporan hasil pengawasan syari'ah sekurang kurangnya setiap enam bulan kepada direksi, komisaris, DSN dan Bank Indonesia." 
dilihat karena faktor ketokohan dalam bidang agama Islam dan bukan pada kompetensi bidang ekonomi dan keuangan syariah.

\section{E. Kesimpulan}

Refleksi seperempat abad kehadiran LKS di Indonesia sejauh ini menunjukkan integrasi prinsip syariah dalam kegiatan LKS belum berlangsung dengan baik. Hal ini antara lain disebabkan norma terkait prinsip syariah itu sendiri, sebagaimana yang tertuang dalam sejumlah fatwa DSN-MUI, yang belum memuat ketentuan yang bersifat teknis dan operasional. Sejumlah fatwa bersifat umum sehingga masih harus ditafsirkan lagi, dan ini pada akhirnya memunculkan interpretasi yang beragam; antara lain menyamakan pembiayaan dengan penyediaan dana. Integrasi prinsip syariah dalam kegiatan intermediasi LKS juga menjadi sulit efektif karena persoalan kelembagaan pengawasan. Sekalipun ada DPS yang memang difungsikan untuk mengawasi LKS, namun hubungannya dengan direksi bersifat koordinatif, dan secara internal perusahaan berarti kedudukannya di bawah dewan komisaris dan pemegang saham. Kebolehan anggota DPS merangkap jabatan pada empat LKS (dua LKS bank dan dua LKS non-bank), dan kebolehan anggota DSN-MUI menjadi anggota DPS, semakin berdampak pada pengawasan yang tidak maksimal. Karena itu, ke depan, dalam rangka mendorong integrasi prinsip syariah yang lebih baik, persoalan terkait norma dalam fatwa DSN-MUI dan persoalan kelembagaan pengawasan LKS, sebagaimana dipaparkan dalam artikel ini, perlu dilakukan perbaikan.

\section{Daftar Pustaka}

\section{Artikel, Buku, dan Laporan}

Abdurrahman, Hafidz. Ushul Fiqih: Membangun Paradigma Berfikir Tasyri’i. Bogor: Penerbit Al-Azhar Press, 2003.

Ascarya. "Comparing Islamic Banking Development in Malaysia and Indonesia: Lessons for Instruments Development”. makalah dalam Diskusi Periodik Directorate of Monetary Management Bank Indonesia, Jakarta, 27/1/2006. 
Budiono, Arief. "Penerapan Prinsip Syariah pada Lembaga Keuangan Syariah". Law and Justice, 2, 1 (2017): 54-65. DOI: 10.23917/laj. v2i1.4337.

Darsono, dkk. Perbankan Syariah di Indonesia: Kelembagaan dan Kebijakan serta Tantangan ke Depan. Jakarta: Rajawali Press, 2017.

Djamil, Fathurrahman. "Pengembangan dan Inovasi ProdukLembaga Keuangan Syariah di Indonesia (Kajian Transaksi Berbasis Syariah dan Hukum Positif)". Kordinat: Jurnal Komunikasi Antar Perguruan Tinggi Agama Islam), 15, 2 (2016): 147-164. DOI: $10.15408 /$ kordinat.v15i2.6327.

Hasanah, Tuti. “Transformasi Fatwa Dewan Syariah Nasional ke dalam Hukum Positif". Syariah: Jurnal Hukum dan Pemikiran, 16, 2 (2016): 161-176. DOI: 10.18592/sy.v16i2.1022.

Haqqi, Abdurrahman Raden Aji. "Shariah Governance in Islamic Financial Institution: An Appraisal”. US-China Law Review, 11 (2014): 112-133.

Huda, Nurul dan Mustafa Edwin Nasution. Investasi pada Pasar Modal Syariah. Jakarta: Kencana Prenadamedia, 2007.

Isra. Islamic Financial System: Principles and Operations. Kuala Lumpur: Isra, 2010.

Latief, Abdul. "Implementasi Fatwa DSN-MUI terhadap Praktik Pembiayaan Murabaḥah Bank Syariah Mandiri dan Bank Muamalat KCP Ponorogo”. Muslim Heritage, 1, 1 (2016): 1-18. DOI: $10.21154 /$ muslimheritage.v1i1.379.

Mansyur, M. Ali. "Aspek Hukum Perbankan Syariah dan Implementasinya di Indonesia”. Jurnal Dinamika Hukum, 11, edisi khusus (2011): 67-75. DOI: 10.20884/1.jdh.2011.11.Edsus.263.

Mardian, Sepky. "Tingkat Kepatuhan Syariah di Lembaga Keuangan Syariah”. Jurnal Akuntansi dan Keuangan Islam, 3, 1 (2015): 57-68. DOI: $10.35836 /$ jakis.v3i1.41.

Maulidiana, Lina. "Penerapan Prinsip-prinsip Murabahah dalam Perjanjian Islam”. Keadilan Progresif, 3, 2 (2012).

Mudzhar, M. Atho, dkk. Fatwa Majelis Ulama Indonesia dalam Perspektif Hukum dan Perundang-Undangan. Jakarta: Badan Libang dan 
Diklat Kementerian Agama, 2012.

Nafis, M. Cholil. Teori Hukum Ekonomi Syariah. Jakarta: UI Press, 2011.

Rodoni, Ahmad dan Abdul Hamid. Lembaga Keuangan Syariah. Jakarta: Penerbit Zikrul Hakim, 2008.

Sjahdeini, Sutan Remy. Perbankan Syariah: Produk-produk dan Aspekaspek Hukumnya. Jakarta: Kencana Prenadamedia, 2014.

Somitra, Andri. Bank dan Lembaga Keuangan Syariah. Depok: Kharisma Putra Utama, 2017.

Syaifullah, Hamli. "Penerapan Fatwa DSN-MUI tentang Murabahah di Bank Syariah". Kordinat: Jurnal Komunikasi Antar Perguruan Tinggi Agama Islam, 17, 2 (2018): 257-282. DOI: 10.15408/ kordinat.v17i2.9612.

Triyanta, Agus. "Implementasi Kepatuhan Syariah dalam Perbankan Islam (Syariah) (Studi Perbandingan antara Malaysia dan Indonesia)". Jurnal Hukum Ius Quia Iustum, 16, edisi khusus (2009): 209-228.

Widodo, Sugeng dan Nuhbatul Basyariah. "Telaah Kritis Implementasi Pembiayaan Murabahah pada Lembaga Keuangan Syariah Berdasarkan KDPPLKS”. At-Tauzi': Jurnal Ekonomi Islam, 20, 1 (2020): 13-22. DOI: 10.37820/attauzi.v20i1.79.

\section{Peraturan dan Fatwa Hukum}

Republik Indonesia. Undang-Undang Nomor 10 Tahun 1998 tentang Perubahan Atas Undang-Undang Nomor 7 Tahun 1992 tentang Perbankan. Lembaran Negara Tahun 1998 Nomor 182, Tambahan Lembaran Negara Nomor 3790.

Republik Indonesia. Undang-Undang Nomor 40 Tahun 2007 tentang

Perseroan Terbatas. Lembaran Negara Tahun 2007 Nomor 106, Tambahan Lembaran Negara Nomor 4756.

Republik Indonesia. Undang-Undang Nomor 21 Tahun 2008 tentang

Perbankan Syariah. Lembaran Negara Tahun 2008 Nomor 94, Tambahan Lembaran Negara Nomor 4867.

Republik Indonesia, Mahkamah Agung. Peraturan Nomor 2 Tahun 2008 tentang Kompilasi Hukum Ekonomi Syariah. 
Republik Indonesia, Bank Indonesia. Peraturan Nomor 6/24/ PBI/2004 tentang Bank Umum yang Melaksanakan Kegiatan Usaha Berdasarkan Prinsip Syariah. Lembaran Negara Tahun 2004 Nomor 122, Tambahan Lembaran Negara Nomor 4434.

Republik Indonesia, Bank Indonesia. Peraturan Nomor 10/16/ PBI/2008 tentang Perubahan atas Peraturan Bank Indonesia Nomor 9/19/PBI/2007 tentang Pelaksanaan Prinsip Syariah dalam Kegiatan Penghimpunan Dana dan Penyaluran Dana serta Pelayanan Jasa Bank Syariah. Lembaran Negara Tahun 2008 Nomor 136, Tambahan Lembaran Negara Nomor 4896.

Republik Indonesia, Bank Indonesia. Peraturan Nomor 11/33/ PBI/2009 tentang Pelaksanaan Good Corporate Governance bagi Bank Umum Syariah dan Unit Usaha Syariah. Lembaran Negara Tahun 2009 Nomor 175, Tambahan Lembaran Negara Nomor 5085 .

Republik Indonesia, Dewan Syariah Nasional Majelis Ulama Indonesia. Fatwa Nomor 04/DSN-MUI/IV/2000 tentang Murabahah. 